\title{
Vegetation Types, Climatic Conditions and Trigona sp. Honey Quality in Onewila Village, Ranomeeto District South Konawe Regency
}

\author{
Jenis Vegetasi, Kondisi Iklim dan Kualitas Madu Trigona sp. \\ di Desa Onewila Kec. Ranomeeto Kab. Konawe Selatan \\ Aminuddin Mane $\operatorname{Kandari~}^{1 *}$, Zakiah Uslinawaty ${ }^{1}$ dan Muh. Ilton ${ }^{1}$ \\ ${ }^{1}$ Department of Environmental Science, Faculty of Forestry and Environmental Science, Halu Oleo \\ University, Southeast Sulawesi, Indonesia \\ ${ }^{*}$ Corresponding author: manekandaria@yahoo.com
}

(Received 28 January 2019, Accepted 27 March 2020)

Citation: Kandari AM, Uslinawaty Z, Ilton M. 2020. Vegetation types, climatic conditions and Trigona sp. honey quality in Onewila Village, Ranomeeto district South Konawe Regency. Jurnal Lahan Suboptimal: Journal of Suboptimal Lands 9(1):57-63.

\begin{abstract}
ABSTRAK
Hutan di Indonesia memiliki potensi yang cukup besar karena disamping dimanfaatkan dalam bentuk kayu untuk berbagai kepentingan, juga memiliki potensi hasil non kayu yang dapat dimanfaatkan untuk berbagai hal, salah satunya adalah sebagai vegetasi pakan bagi lebah madu khususnya lebah Trigona sp. Penelitian ini bertujuan untuk mengetahui jenis vegetasi, kondisi iklim dan kualitas madu Trigona sp. di desa Onewila Kecamatan Ranomeeto. Variabel yang diamati adalah jenis vegetasi dan populasi, kondisi iklim (suhu udara dan curah hujan), dan kualitas madu berdasarkan standar SNI 2013. Hasil penelitian menunjukkan bahwa jenis vegetasi yang terdapat pada lokasi budidaya Trigona sp ada 13 jenis dengan populasi berbeda-beda, yaitu: jenis kaliandra (Calliandra calothyrsus $=10$ ), kelapa (Cocos nucifera $=12)$, jati (Tectona grandis $=20)$, ruruhi (Syzygium polycephalum Merr $=7$ ), mangga (Mangifera indica $=5$ ), langsat (Lansium domesticum $=15$ ), kedondong $($ Spondias dulcis $=3)$, jambu (Psidium guajava $=4)$, pinang $($ Areca catechu $=10)$, kopi $($ Coffea arabica $=15)$, jambu mete (Anacardium occidentale $=15)$, Sirsak ((Annona muricata $=2$ ), bunga asoka (Saracca asoca $=5$ ). Kondisi suhu udara dan curah hujan di lokasi budidaya sangat menunjang budidaya Trigona sp karena rata-rata suhunya berkisar $29^{\circ} \mathrm{C}$, dan curah hujan rata-rata bulanan di stasiun Ranomeeto tertinggi pada bulan Januari (135 mm) dan terendah pada bulan Agustus $(16.8 \mathrm{~mm})$. Kualitas madu dari madu Trigona sp. dari beberapa variabel seperti kadar air, kadar keasaman, kadar HMF, dan kadar gula pereduksi masing-masing adalah $16.98 \%, 33.94 \mathrm{mg} / \mathrm{kg}, 17.3 \mathrm{mg} / \mathrm{kg}, 69.31 \% \mathrm{~b} / \mathrm{b}$. Hal ini berarti kualitas madu Trigona sp yang terdapat di desa Onewila memenuhi Standar Nasional Indonesia (SNI 01-3545-2013 2013).
\end{abstract}

Kata kunci: budidaya, iklim, lingkungan, pakan, trigona

\begin{abstract}
Forests in Indonesia have considerable potential because besides being used in the form of wood for various purposes, it also has the potential of non-timber products that can be used for various things, one of which is as a vegetation for honey bees, especially bees Trigona sp.This study aims to identification of vegetation types, climatic conditions and honey quality of Trigona sp. in the Onewila village, Ranomeeto District South Konawe
\end{abstract}


Regency. The observed variables were vegetation, temperature, rainfall, and honey quality based on SNI 2013 standards. The results found the vegetation types at the cultivation location was Caliandra (Caliandra calothyrsus $=10)$, coconut $($ Cocos nucifera $=12)$, teak $($ Tectona grandis $=20)$, peat (Syzygium polycephalum Merr $=7)$, mango (Mangifera indica $=5)$, langsat (Lansium domesticum $=15)$, kedondong (Spondias dulcis $=3)$, guava (Psidium guajava $=4)$, areca $($ Areca catechu $=10)$, coffee $($ Coffea Arabica $=15)$, cashew nut (Anacardium occidentale $=15$ ), areca nut (Areca catechu), coffee (Coffea arabica), cashew nut (Spondias dulcis), Cashew nut (Anacardium occidentale $=15)$, Sirsak ((Annona muricata $=2$ ), and asoka flowers (Saraca asoka $=5)$. The air temperature and rainfall conditions in the location is very supportive of Trigona cultivation because the average of air temperature ranges from $29^{\circ} \mathrm{C}$, and the average monthly rainfall at Ranomeeto station is highest in January $(135 \mathrm{~mm})$ and lowest in August $(16.8 \mathrm{~mm})$. The honey quality of Trigona sp, from several variables such as water content, acidity, HMF levels, and reducing sugar levels are $16.98 \%, 33.94 \mathrm{mg} / \mathrm{kg}, 17.3 \mathrm{mg} / \mathrm{kg}, 69.31 \% \mathrm{~b} / \mathrm{b}$. This means that the honey quality of Trigona sp found in Onewila village meets the Indonesian National Standard (SNI 01-3545-2013 2013).

Keyword: climate, cultivation, environment, feed, trigona

\section{INTRODUCTION}

Forest with various functions and benefits provides a huge influence, either directly or indirectly to the ecological, economic and social. (Torres-Rojo et al., 2016) states that the use of forests to extract timber are now starting to switch to the use of non-timber forest products that lead to sustainable forest management. By Sidik (2009), NTFPs that many try by farmers in Indonesia one of which is a wild honey bee. Further explained that a honey bee is an insect that has long been known to man, where since the first humans seek beehive in caves, in holes, trees, and in other places to get the honey.

Nowadays people have started cultivating honeybees. Beekeeping honey if modern managed intensively and will provide direct and indirect benefits. Siregar et al., (2011) states that the direct benefits that can be derived from honeybees, which produces a wide range of honey bee products such as honey, royal jelly, propolis, pollen, wax, adhesive and bee venom. The indirect benefits to be gained beekeeping that is related to the preservation of forest resources, increasing crop productivity and their mutually beneficial symbiotic relationship (Melissa, 2008); Siregar et al. (2011). Susanto (2012) states that the production and the type of honey produced by honey bees depend on natural vegetative flowers that bloom in different seasons. Indonesia has several types of honey based flora is the source of the nectar. According to Sihombing (2005) composition of honey is determined by two main factors namely, the origin of honey nectar composition in question and certain external factors resulting quality of honeybee products is determined by climatic conditions and vegetation types. The state of the elements of this climate will affect behavior and metabolism take place in living organisms (Prawirowardoyo, 1996). Honeybees produce their products by utilizing the feed source (vegetation) that is around, while vegetation is affected by climatic conditions around it. Trigona sp. Village Onewila Ranomeeto District of South Konawe, with the aim to determine the vegetation types and population, climatic conditions and the honey quality of Trigona sp. compared with the Indonesian National Standard (SNI 01-3545-2013 2013) (BSN, 2013).

\section{MATERIALS AND METHODS}

\section{A. Location and Time Research}

The research was conducted in the village of Onewila, District Ranomeeto, 
South Konawe on the location of bee Trigona sp owned by farmers. Continued Laboratory and Laboratory of the Science Faculty of Forestry FHIL UHO. The research was conducted at the beginning of January - end of June 2019.

\section{B. Materials and Tools}

The materials used for this study are: Tally sheet, sample honey Trigona sp., Reagents used to test the honey quality, which is comprised of: A solution Carrez I, a solution of Carrez II, Sodium bisulfite $\left(\mathrm{NaHSO}_{2}\right)$, solution of sodium hydroxide, $\mathrm{NaOH}$ 0, $1 \mathrm{~N}$ free karbonal, fenoftalein Indicators, pp $1 \%$ in ethanol, neutral, distilled water. Tools used: GPS, camera, thermometer, oven, spectrophotometer, analytical balance, volumetric flask, pipette, burette, beaker, heating, test tubes, stationery and paper filter.

\section{Observation Variables}

The observed variables in this study:

1. Vegetation types,

2. Climate conditions,

3 . Test the honey quality by the standards of ISO 2013.

\section{Obsevation Procedure}

1. Observing the vegetation types, the vegetation to collect samples from farms Trigona sp to be identified;

2. Viewing the climate conditions, especially the air temperature at the location of the cultivation of Trigona $\mathrm{sp}$, while precipitation derived from weather stations Ranomeeto;

3. Test the honey quality by the standards of ISO 2013, collecting honey samples were further tested by several indicators, namely the Water Content, Acidity levels, levels of HMF and reducing sugar levels.

\section{E. Data Analysis}

\section{The vegetation Types and population}

The identification results of vegetation, tabulated by type so we get many types of vegetation and abundance of each species found in the field;

\section{The Climatic Conditions}

a) The air temperature, calculated based on the measurement of thermometer placed in farms Trigona sp.

b) The rainfall of annual averages and monthly averages, calculated from the average rainfall every month for 4 years of observation (2015-2018) in the Month of year Jan-Des, data from Ranomeeto Station;

c) The rainfall is the monthly average of the highest and lowest calculated based on the monthly average rainfall;

d) The climate type, analyzed using Schmidth-Fergusson, where the climate is divided into eight types based on comparison of average amount in dry and wet months stated in the $\mathrm{Q}$ value (quotient) in Table 1 . Dry Months (DM), the months with rainfall $<60 \mathrm{~mm}$, wet months (WM) rainfall $>100 \mathrm{~mm}$, humid month $(\mathrm{HM}) \geq$ rainfall $60-100 \mathrm{~mm}$ (Lakitan, 2002).

Table 1. Climate classification methods schmidthfergusson

\begin{tabular}{lll}
\hline \multicolumn{1}{c}{ Climate type } & Vegetation & Criteria \\
\hline A. Very wet & Tropical rain fores & $0,000<\mathrm{Q}<0,143$ \\
B. Wet & Tropical rain fores & $0,143<\mathrm{Q}<0,333$ \\
C. Somewhat wet & Jungle & $0,333<\mathrm{Q}<0,600$ \\
D. Medium & Forest season & $0,600<\mathrm{Q}<1,000$ \\
E. Somewhat dry & Savanna forest & $1,000<\mathrm{Q}<1,670$ \\
F. Dry & Savanna forest & $1,670<\mathrm{Q}<3,000$ \\
G. Very dry & Grassland & $3,000<\mathrm{Q}<7,000$ \\
H.Extraordinary dry & Grassland & $7,000<\mathrm{Q}$ \\
& &
\end{tabular}

\section{The Honey Quality}

To determine the honey quality Trigona sp testing multiple parameters compared with SNI requirements (Table 2).

Table 2. Value of honey quality requirements

\begin{tabular}{lcl}
\hline The Parameters Tested & Unit (\%) & $\begin{array}{l}\text { Good Quality } \\
\text { Value }\end{array}$ \\
\hline Water Content (Ka) & $\%$ & $22 \mathrm{Min}$ \\
Acidity Levels (KK) & $\mathrm{ml} \mathrm{NaOH} \mathrm{1} \mathrm{N/kg}$ & $50 \mathrm{Min}$ \\
HMF Levels & $\mathrm{Mg} / \mathrm{kg}$ & $50 \mathrm{Min}$ \\
Reducing Sugar Levels & $\% \mathrm{~W} / \mathrm{w}$ & at least 65 \\
\hline
\end{tabular}

Source: National Bureau of Standards (2013) 


\section{RESULTS}

\section{The Vegetation Types and Population}

The results of the identification of the vegetation types and the population at about Trigona sp farming area (Figure 1).

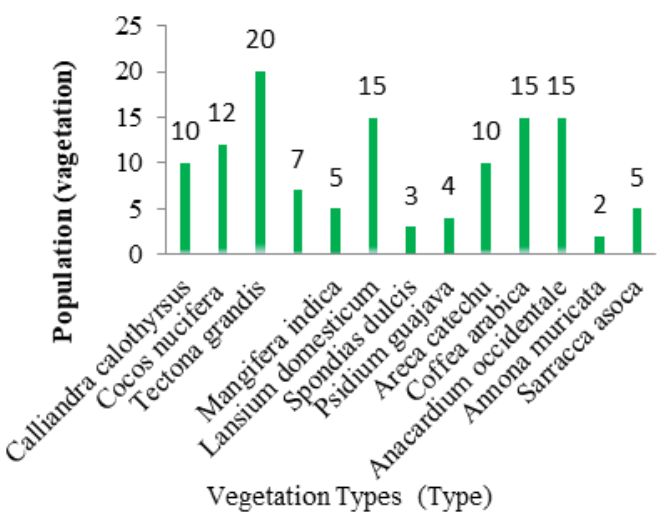

Figure 1. The presence of vegetation and population on farms Trigona $\mathrm{sp}$ in the village of the district Onewila Ranomeeto South Konawe

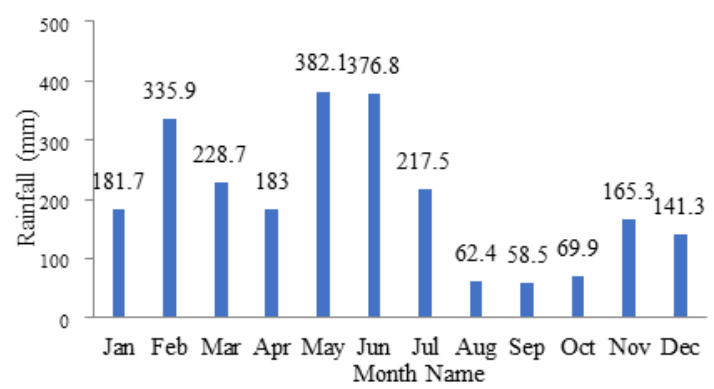

Figure 2. Fluctuations rainfall (mm) monthly average in the village Onewila Ranomeeto District of South Konawe Based in Climatology Station Recording Ranomeeto the last four years (20152018)

Table 3. Results of honey quality testing Trigona sp on raising bees village location Onewila Ranomeeto District of South Konawe

\begin{tabular}{lrrr}
\hline $\begin{array}{l}\text { Quality Indicators } \\
\text { Honey }\end{array}$ & $\begin{array}{c}\text { Test } \\
\text { Results }\end{array}$ & SNI & Description \\
\hline Water Content (\%) & 16.98 & 22 & Maximum \\
Levels of Acidity (kg) & 33.94 & 50 & Maximum \\
Level of HMF (mg kg & 17.73 & 50 & Maximum \\
Levels of Reducing & 69.31 & 65 & Minimum \\
Sugars (\% w/w) & & & \\
\hline \multicolumn{2}{l}{ Primary data is processed, 2019 } &
\end{tabular}

\section{The Climatic Conditions}

In general, the village Onewila Ranomeeto District of South Konawe located at an altitude of $30 \mathrm{~m}$ above sea level, has two seasons namely dry and rainy with an average annual rainfall of the last 4 years (period 2015-2018) of $2402.9 \mathrm{~mm} / \mathrm{yr}$ and air temperature ranging between 23$32^{\circ} \mathrm{C}$ with an average of $29^{\circ} \mathrm{C}$. Substitution of the dry season and the rainy season is influenced by the wind direction is West wind power in June to January and wind East/Southeast February to August. Fluctuations in rainfall monthly averages presented in Figure 2.

\section{The Honey Quality}

The results of the analysis of the honey quality Trigona sp derived from the study site are presented in Table 3.

\section{DISCUSSION}

Based on the results of the identification of the type of vegetation and the population in Figure 1), it can be argued that the type of vegetation in the research area covers vegetation bloom, so automatically have nectar and is suspected to be a source of feed bees. The fact that according to the statement Kasno (2001) that the bees happy at that flowering vegetation to feed. Sarwono (2001) stated that all types of flowering plants (plants of forest, agricultural crops, plantation crops, horticultural crops and wild plants) which lack the element of nectar as an ingredient of honey, pollen and propolis resin as the material can be used as feed for bees. The fact is also in line with the report Ilton (2019) about the types of vegetation found on farms around Trigona sp. in the village of the District Onewila Ranomeeto Konsel district (Figure 1).

Ramalho et al. (1990) states that honey and propolis produced by bees Trigona $\mathrm{sp}$ is determined by the presence of plants as a food source around the nest. Further explained that the abundance of sources of high feed will increase the production of honey and bee propolis Trigona, especially the type of vegetation or plants as a food source in the form of pollen and nectar, 
such as Impatiens balsamina, Carica papaya, Ageratum houstonianum, Psidium guajava, Helianthus sp, Acacia sp, Caliandra brevipes, Mimosa pudica, Capsicum sp and Cocos nucifera.Such plants are mostly found in farms Trigona on empirically location. This means that farms in the village Trigona Onewila according to the location because of the availability of plant cultivation, which feed the bees Trigona .

Figure 2 shows that the average rainfall is the highest monthly occurred in May that is $382.1 \mathrm{~mm}$, while the lowest occurred in September which is $58.5 \mathrm{~mm}$. Based on the criteria according to the monthly rainfall Schmidth method - Fergusson, then in the village Onewila study sites are the average number of wet months (WM) and averaged 9.3 dry months (DM) 2.0 so that it has a Quetion value of 0:22. The condition indicates that the location of tropical research of type B or relatively wet climate with tropical rain forest vegetation, however, observations of air temperature ranging between $23-32^{\circ} \mathrm{C}$ with an average of $29^{\circ} \mathrm{C}$, indicating also that the farming location Trigona sp the village Onewila rather hot tropical climates. This fact is also in line with the statement Devanesan et al. (2002) that the bees Trigona sp are found in tropical regions with hot climates compared to temperate with four seasons.

Widhiono (1986) stated that in the life and development, the bee is strongly influenced by environmental factors. In addition to the availability of food, environmental factors such as temperature, humidity, rainfall and altitude also determine the development of the honey bee. According Koneri et al. (2010), the success of live bees Trigona $\mathrm{sp}$ in the tropics can not be separated from its ability to live in a wide temperature range. Further stated that the diversity of insects that exist in each place including bees Trigona sp influenced by several factors, one of which is the height of the place including the air temperature. According to Pratama (2016) colonies of bees Trigona sp can live in coastal areas up to $800 \mathrm{~m}$ above sea level, and is therefore in accordance study site because it has a height of $30 \mathrm{~m}$ above sea level.

Marhiyanto (1999) states that the rainfall influence the development of Trigona sp, especially on the feed provided when the rainfall is too high then the bees will be difficult to find food but it also will lead to the nectar and pollen of plants feed the bees is reduced along with the high rainfall somewhere, otherwise the low rainfall caused the bees can thrive, especially in the research area which is characterized by ever-growing number stup.

Relation to the quality of honey, the test results showed all the indicators are in the appropriate category SNI, even on the indicator of water content is much lower than the SNI with a maximum value of $22 \%$ while in the farming area of Trigona in the village Onewila water level is only $16.8 \%$, thus indicating that the honey Trigona sp The village Onewila is of high quality. This fact is consistent with the Priyanto (2012) statement that the lower the water content in honey produced the better the quality. According to Siregar (2002) and Sihombing (2005), the water content can determine the degree of durability of honey, affect the crystallization and fermentation, where low water levels will keep the honey of damage for a relatively long period, while the higher the water content, the more easily the fermentation. White (1979) states that the acidity of honey is an important criterion to determine the quality of honey, which if high acidity means that the honey has undergone fermentation and low acidity level if the mean has not undergone fermentation. Further explained that the acidity of honey is strongly influenced by the origin of the most dominant nectar as a source of honey bee food.

According Tanuwidjaya (2014), honey with a low HMF content value indicating the low addition of invert sugar in honey, also indicated still in a fresh state (Boussaid et al., 2014; Amalia, 2016). Increased levels of HMF in honey after heating within 
60 minutes, Chua et al. (2014); Amalia (2016). According to Zakaria (2013) that the levels of HMF in honey can be affected by several factors such as temperature, heating time, the storage conditions and the source of the nectar. According Achmadi (1991) and Wulandari (2017) the longer storage and higher storage temperature will reduce the activity of the enzyme that produced reducing sugar will also be lower.

Based on the survey results revealed that out of the four parameters of honey quality obtained results that match the quality of honey quality standards according to SNI 01-3545-2013.

\section{CONCLUSION}

Based on the research results, it can be summarized as follows:

1) The vegetations types found on farms

Trigona sp in Rural Onewila there are 13 types with a different population, namely: the type Caliandra (Caliandra calothyrsus $=10), \quad$ coconut $\quad($ Cocos nucifera $=12), \quad$ teak (Tectona grandis $=20), \quad$ ruruhi $\quad($ Syzygium polycephalum Merr=7), mango (Mangifera indica $=5$ ), langsat (Lansium domesticum=15), kedondong (Spondias dulcis $=3)$, guava (Syzygium aqueum $=4)$, peat (Areca catechu=10), coffee (Coffea Arabica $=15), \quad$ cashew (Anacardium occidentale $=15), \quad$ soursop (Annona muricata $=2)$, and interest Ashoka (Saraca asoka=5).

2) The climatic conditions of the location study strongly support the cultivation of Trigona sp, because the average temperature fluctuates between $29^{\circ} \mathrm{C}$ and rainfall is the highest monthly average in May $(382.1 \mathrm{~mm})$ and the lowest in September $(58.5 \mathrm{~mm})$, rainfall annual average of $2402.9 \mathrm{~mm}$, classified as a type B climate or vegetation wet with Tropical Rain.

3) The honey quality Trigona sp of several variables such as moisture content, acidity, HMF levels, and reducing sugar levels, respectively 16.98\%, $33.94 \mathrm{mg} /$ $\mathrm{kg}, \quad 17.3 \mathrm{mg} / \mathrm{kg}, \quad 69.31 \% \mathrm{w} / \mathrm{w}$. This means that the quality of honey Trigona sp located in the village Onewila meet the Indonesian National Standard (SNI 01-3545-2013 2013) (BSN, 2013).

\section{ACKNOWLEGEMENT}

Thanks to the Chairman of the Department of Forestry, Faculty of Forestry and Environmental Science haluoleo university that has been providing support to the team of authors to guide you Muh. Ilton in collecting research data used in addition to the thesis, also developed by several variables in a special study so that the realization of this article Also To the head of UHO FMIPA laboratory that has supported in the analysis of the quality of honey were studied. Special to the honey bee farmers in the village of Onewila our research team to thank them for their cooperation.

\section{REFERENCES}

Achmadi S. 1991. Analysis of Honey Bee Products Chemistry and Laboratory Staff Training Center of the National Beekeeping Parung Panjang. Faculty of Mathematics and Natural Sciences University. Bogor.

Amalia L. 2016. Characterization of Physicochemical Honey multiflora Home Videos And Effectiveness Of Escherechia coli and Staphylococcus aureus [thesis] Bogor Agricultural University in Bogor.

Boussaid A, Chouaibi M, Rezig L, Hella R, Donsi F, Ferrari G, Hamdi S. 2014. physicochemical and bioactive properties of six honey samples from various floral origins from Tunisia. Arabian J Chem. 30 (60): 1-10.

Boussaid A, Chouaibi M, Rezig L, Hella R, Donsi F, Ferrari G, Hamdi S. 2014. physicochemical and bioactive properties of six honey samples from various floral origins from Tunisia. Arabian J Chem. 30 (60): 1-10. 
BSN (National Bureau of Standards), 2013. SNI 01-3545-2013. Honey.

Chua LS, NA Adnan Abdul-Rahaman NL, Sarmidi MR. 2014. Effect of thermal treatment on the biochemical composition of tropical honey samples. I Food RJ. 21 (2): 773-778.

Devanesan S, MM Nisha, R. Bennett, and KK Shailaja. 2002. Foraging behavior of stingless bees, Trigona iridipennis Smith. Insect Environ. 8 (3): 131-133.

Ilton M. 2019. The quality honey of Trigona sp on three farms in South Konawe.

Kasno. 2001. Feeding bees. Faculty of Forestry. IPB. Bogor.

Koneri R, Solihin DD, Buchori D, and Tarumingkeng R. 2010. Biodiversity Lucanid Beetles (Coleoptera: Lucanidae) on Various Altitude In the Forest Concession Unocal Mount Salak. Sam Ratulangi University. Manado.

Lakitan B. 2002. The basics of climatology. Jakarta: King Grafindo Persada.

Marhiyanto B. 1999. The honey bee husbandry business opportunities. Media Gita Press. Surabaya.

Melissa. 2008. StudiPengembangan. NonTimber Forest. Rajawali Press. Jakarta.

Prawirowardoyo, S. 1996. Meteorology. Bandung Institute of Technology Press, Bandung.

Pryanto. 2012. Quality Test Honey Bees Trigona sp. on the Cultivation of Honey Bees in Lalomba Village District of Kolaka District. Kolaka. Department of Forestry. Faculty of Agriculture. Etc. Halu Oleo. Kendari.

Ramalho M, Giovannini AK, Fonseca VLI. 1990. Important bee plants for stingless bees (Melipona and Trigonini) and Africanized Honeybees (Apis mellifera) in neotropical habitats. Apidologie, 21. 469-488.

Sarwono B. 2001. Honeybees. Agro media library. Jakarta.

Sidik A. 2009. Efficacy and Benefits of Honey Bee. CV. Walatra, Bandung.
Sihombing DTH. 2005. Honey Bee Animal Science. Yogyakarta: Gadjah Mada. University Press.

Siregar HC. 2002. Effect of moisture reduction method, temperature and storage time on the quality of honey cottonwoods. [Thesis] Bogor: Graduate. IPB.

Siregar HC, Fuah AM, Octavianty Y. 2011. Propolis; Multikhasiat honey. Sower Governmental Group.

Susanto A. 2012. Composition Structure Nature Reserve Vegetation in Manggis Gadungan Region. Agri-tek. 13 (2): 7887.

Tanuwidjaya SJ, 2014. Characteristics Of Chemical And Appearance Honey Bee Apis mellifera, Apis cerana, Apis dorsata and Trigona sp.Fakultas Ranch. Bogor Agricultural Institute. Bogor.

Torres-Rojo JM, Moreno-Sánchez R, Martin, Mendoza-Briseño A. 2016. Sustainable Forest Management in Mexico. Curr Forestry Rep, 2, 93-105. https://doi.org/10.1007/s40725-0160033-0.

White JW. 1979. Physical characteristic of honey. inclusive; Crane, E (ed). Honey: A Comprehensive Survey. Heinemann. London.

Widhiono I. 1986. Environmental Factors Influencing Cells In Addition To The Bee Honey strokes. Cultivation of Honey Bees Proceedings of the Workshop for Community Welfare Improvement. Perum Perhutani. Jakarta.

Wulandari DD 2017. Honey Quality (acidity levels, water levels, and reducing sugar levels based on storage temperature). Journal of Chemical Research Vol 2. \# 1, Department of Chemistry, Faculty of Science and Technology, Airlangga University Surabaya.

Zakaria. 2013. Analysis of levels of HMF (Hidroxymethilfulfural) on Bone honey. Programs MT. State Islamic High School Watampone. Bone County. South Sulawesi. 